\title{
The role of benthic biofilm production in the mediation of silicon cycling in the Severn Estuary, UK
}

Welsby, H.J. ${ }^{1,2}$, Hendry, K.R. ${ }^{2}$, Perkins, R.G. ${ }^{1}$

${ }_{1}$ School of Earth and Ocean Science, Main Building, Cardiff University, Cardiff, CF10 3AT, UK.

${ }_{2}$ School of Earth Sciences, University of Bristol, Wills Memorial Building, Queens Road, Bristol, BS8 1RJ, UK.

\section{Abstract}

1 The biological mediation of benthic biogenic silica (BBSi) by the diatom-dominated

2 biofilms on the intertidal mudflats of the Severn Estuary (UK) was assessed in situ

3 under different environmental conditions using measurements of productive biomass

4 (chlorophyll a), photosynthetic activity of undisturbed microalgal assemblages, benthic

5 biogenic silica (BBSi) and benthic dissolved silica (BDSi). We show low BBSi standing

6 stocks in the mudflats compared to other European estuaries, under both warmer

7 summer conditions (0.6\%) and colder winter conditions (0.5\%). Dissolved forms of $\mathrm{Si}$

8 (BDSi) dominated the estuary, with significantly higher concentrations during the

9 sampled winter $\left(22.6 \pm 1.0 \mathrm{mg} \mathrm{L}^{-1}\right)$ compared to the sampled summer $\left(2.9 \pm 0.5 \mathrm{mg} \mathrm{L}^{-}\right.$

$\left.10{ }^{1}\right)$. Benthic algal biomass was higher under cold conditions compared to warmer

11 conditions $\left(24.0 \pm 2.3\right.$ and $13.2 \pm 1.9 \mathrm{mg} \mathrm{g}^{-1}$ sed. $d w$., respectively), following reduced

12 migratory behaviour in the winter increasing surficial biomass. Relative maximum

13 Electron Transport Rate $\left(\mathrm{rETR}_{\max }\right)$, used as a proxy for relative primary productivity,

14 was higher under warm conditions (254.1 \pm 20.1 rel. units) compared to cold conditions

15 (116.0 \pm 27.1 rel. units). The biofilms sampled in the summer biologically mediated $\mathrm{Si}$

16 by the productive, high light acclimated diatoms that were highly motile during

17 fluorescence measurements, and exhibited migratory behaviour, which despite

18 nutrient limitation, evidenced by low $F_{v} / F_{m}$, increased the accumulation of BBSi. The

19 biofilms sampled in the winter that were subject to relatively colder temperatures,

20 consisted of low light acclimated diatoms of reduced migratory capabilities, and

21 induced NPQ that suppressed productivity, and mediated BBSi to a lesser extent.

22 Environmental stresses reduced biofilm mediation of $\mathrm{Si}$, which, in addition to high 
23 hydrodynamic energy increasing biofilm re-suspension, controlled Si to a lesser extent

24 compared to terrestrial/coastal inputs.

\section{Keywords}

26 Biogenic silica, benthic, biomass, primary productivity, downregulation.

\section{Introduction}

28 Most research on the global silicon (Si) cycle has focused on weathering (Hurd, 1977;

29 West et al. 2005; Fortner et al. 2012) or oceanic Si cycles (Brzezinski et al. 1998; Yool

30 \& Tyrrell, 2003). Few have explored the complexity of the marine-terrestrial 31 interconnecting cycles, leaving estuarine processes poorly constrained despite their 32 importance in determining marine Si budgets. The present study intends to address 33 the lack of research on Si cycling in the coastal transition zone. This was achieved by 34 analysing the variations in $\mathrm{Si}$ fractions in the Severn Estuary, resulting from 35 environmental driven changes in the ecosystem functioning, in the form of biomass 36 and relative primary productivity, by the exposed diatom-dominated (Underwood, 2010) microphytobenthos (MPB) biofilms on the intertidal mudflats.

The high water turbidity, typical of a sediment-dominated estuary, limits the growth of large pelagic phytoplankton communities (Underwood, 2010). Subsequently, the MPB biofilms have high rates of biogeochemical cycling, with complex rhythms of photosynthetic activity (Pickney \& Zingmark, 1991), and are likely to mediate nutrient dynamics in an estuary. MPB are characterized by the absence of photo-inhibition at high irradiance, due to the combination of physiological (e.g. effective photochemical and non-photochemical quenching, NPQ; see Maxwell \& Johnson, 2000; Jesus et al. 2006; Lavaud \& Kroth, 2006) and behavioural mechanisms (bulk migratory response), and cell surface turnover in the form of micro-cycling, minimizing the risk of overexposure to damaging light intensities (Kromkamp et al. 1998; Serôdio et al. 2006b, 2008; Perkins et al. 2001, 2002, 2010). No previously published studies have investigated the diatom-dominated MPB biofilms influence on Si dynamics in the Severn Estuary.

51 The Severn Estuary is a heterogeneous environment with a complex hydro52 geomorphology (Kirby, 2010; Manning et al. 2010), resulting in an important 53 environment for biosphere functioning, primarily through the filter for land-ocean 54 exchange. The hyper-tidal range is the second highest astronomical tide globally (13.9 
$\mathrm{m}$ at Avonmouth) (Liang et al. 2013) resulting in substantial intertidal areas of cohesive muddy sediment. This makes the Severn Estuary an important case study for Si cycling, and allows for scaling to quantify other estuarine Si budgets. Few estuarine Si studies exist globally (De'Elia et al. 1983; Rendell et al. 1997; Liu et al. 2005; 2008; 2009; Arndt \& Regnier, 2007; Pastuszak et al 2008; Carbonnel et al. 2009; 2013), and understanding of the controls on the current $\mathrm{Si}$ cycle and estuarine budgets are lacking. The Scheldt Estuary, Belgium/The Netherlands, remains one of the only estuaries to have a comprehensive $\mathrm{Si}$ dataset, and has proven to enhance biological processes leading to nutrient transformations (Arndt \& Regnier, 2007; Carbonnel et al. 2009; 2013). Similarly, the fine-sediment dominated Severn Estuary may exhibit a significant biological control on Si dynamics. Further, the strength of the inter-habitat coupling in the estuary implies that changes in MPB biomass and productivity may propagate into other linked ecosystems, and further afield to the marine pelagic zone in the southwest.

$\mathrm{Si}$ is a key element for siliceous organisms in aquatic habitats. Land-sea interactions and transfers control the proportions of $\mathrm{Si}$ in the form of silicic acid $\mathrm{Si}(\mathrm{OH})_{4}$, hereafter called 'dissolved silica' (DSi), and particulate biogenic silica (BSi). These vary seasonally and geographically due to the transformation from DSi to BSi ( 240 t mol $\mathrm{y}^{-1}$ ) by photoautotrophic motile epipelic diatoms (accounting for $>95 \%$ of eukaryotic living cells on intertidal mudflats) (Underwood, 2010), and weathering processes, a factor of river flow regime and temperature (Ragueneau et al. 2000). The variation in the natural abundance of $\mathrm{Si}$ fractions has often been used as a proxy for diatom production and Si utilization (Conley \& Malone, 1992). Therefore, characterizing the difference in Si fractions provides important information on Si biological uptake in the estuary.

Si cycling is poorly quantified from local to global scales due to the lack of Si data compared to other key nutrients (Moosdorf et al. 2011). Previous studies (Conley \& Malone, 1992; Aure et al. 1998; Gilpin et al. 2004) have noted non-Redfield ratios (Redfield et al. 1963) in estuaries. For example, in sub areas of the Baltic Sea, the doubling of phosphate and nitrate inputs increased BSi production causing a reduction in DSi, and induced Si limitation (Pastuszak et al. 2008). Such nutrient ratios can diminish the relative importance of diatoms, resulting in non-siliceous phytoplankton becoming dominant (Correll et al. 2000). Despite the Severn Estuary's ecological and economic importance, its role in benthic BSi (BBSi) and benthic DSi (BDSi) transformations, to our knowledge, has not been addressed quantitatively. This gap 
leaves little understanding of the terrestrial disturbances by anthropogenic activities, land-use changes, and climate change expected over the twenty-first century (Met Office, 2011). The aim of this study was to analyse the biological mediation of Si by the diatom-dominated MPB biofilms in the Severn Estuary under different environmental conditions, resulting from investigating three separate survey sites under summer and winter conditions. This was achieved through the analysis of different environmental conditions experienced during the summer (relatively warmer, lower rainfall) and a winter (relatively colder, higher rainfall), and over a spatial scale of the three sample sites that differed in sediment water content and site exposure.

\section{Methods}

\section{Study site and sampling method}

The study was carried out on intertidal mudflats located in the Severn Estuary between southeast Wales and southwest England (Fig. 1). Three intertidal mudflat sites were surveyed: site 1, Severn Beach $\left(002^{\circ} 66^{\prime} \mathrm{W}, 051^{\circ} 56^{\prime} \mathrm{N}\right)$; site 2, Portishead $\left(002^{\circ} 77^{\prime} \mathrm{W}\right.$, $\left.051^{\circ} 49^{\prime} \mathrm{N}\right)$; and site 3 , Newport Wetlands $\left(002^{\circ} 58^{\prime} \mathrm{W}, 051^{\circ} 32^{\prime} \mathrm{N}\right)$. Site 1 mudflats located at the mouth of the River Severn, subject to a small tidal prism, were exposed to the full-force of the prevailing south westerly winds, and had sediments of high sand content $(>63 \mu \mathrm{m})$. Site 2 mudflats were less exposed to the south westerly winds, and had higher mud content $(<63 \mu \mathrm{m})$, and crevasses perpendicular to the shoreline. Site 3 mudflats, subject to a large tidal prism, were sheltered from the south westerly winds, and had high mud content $(<63 \mu \mathrm{m})$, and laid adjacent to a saltmarsh and wetlands.

In situ MPB biofilms were sampled during daytime low tide periods in the summer and winter of 2014. Air temperature records for the Severn Estuary show a significant difference $(t(d f)=13.224, p<0.001)$ between the relatively warmer summer and relatively colder winter sampling periods (Fig. 2) (Met Office, 2015). The benthic biofilms sampled during the summer were exposed to longer sunshine hours and lower rainfall ( $225 \mathrm{hrs}$ sunshine, $79.6 \pm 28.2 \mathrm{~mm}$ of rain) compared to biofilms sampled during the winter (64 hrs sunshine and $136.8 \pm 28.6 \mathrm{~mm}$ of rain) (Met Office, 2015).

At each site, 12 sampling stations were surveyed, equally spaced along a linear transect parallel to the lower shore. Sampling involved extracting sediment mini-cores of a diameter of $2.54 \mathrm{~cm}$ for the surficial $5 \mathrm{~mm}$ biofilm for analyses of chlorophyll a content (chl a) (Smith \& Underwood, 1998), key benthic diatom species, and BBSi 
122 content. Pore fluids (25 $\mathrm{ml})$ at each station were sampled for BDSi and orthophosphate

123 (P) concentrations using a simplified peeper method (Teasdale et al. 1995).

\section{BBSi}

125 Approximately $25 \%$ of the surficial $5 \mathrm{~mm}$ biofilm sediment was placed in an oven at $12685^{\circ} \mathrm{C}$ for $24 \mathrm{~h}$ to determine the percentage loss of weight upon drying. BBSi 127 concentrations were determined following the standard alkaline extraction method for 128 marine sediment (DeMaster, 1981) and presented as percentage of dried Si mass 129 ( $\mathrm{g} / \mathrm{g})$. Dried sediment was crushed using a pestle and mortar, and $\sim 0.05 \mathrm{~g}$ of the 130 sediment was leached in hydrogen peroxide (5 ml of $10 \% \mathrm{H}_{2} \mathrm{O}_{2}$ solution), followed by 131 acid ( $5 \mathrm{ml}$ of $1 \mathrm{M} \mathrm{HCl}$ solution). To each sample, $40 \mathrm{ml}$ of $0.1 \mathrm{M}$ of $\mathrm{NaCO}_{3}$ was added. 132 Samples were placed in a covered, constant temperature water bath at $85^{\circ} \mathrm{C}$. After 1

$133 \mathrm{~h}, 3 \mathrm{~h}$ and $5 \mathrm{~h}$, sub samples were taken, diluted, neutralized, and analysed for BBSi 134 content using the standard Heteropoly Blue Method, and measured using a Hach 135 Lange DR3900 spectrophotometer.

\section{BDSi and orthophosphate $\left(\mathrm{P}^{-} \mathrm{PO}_{4}{ }^{-}\right)$}

137 Pore fluid samples were centrifuged for $10 \mathrm{~min}$ at $1000 \mathrm{rpm}$ for $\mathrm{BDSi}$ and $\mathrm{P}_{-} \mathrm{PO}_{4}{ }^{-}$ 138 concentrations. BDSi was analysed using the Heteropoly Blue method with 139 concentrations $\left(\mathrm{mg} \mathrm{L}^{-1}\right)$ measured using a Hach Lange DR3900 spectrophotometer. $140 \mathrm{P}-\mathrm{PO}_{4}^{-}$concentrations $\left(\mathrm{mg} \mathrm{L}^{-1}\right)$ from pore fluids were measured using a Hach Lange 141 DR3900 spectrophotometer, where $2.0 \mathrm{ml}$ of each sample were analysed following the 142 LCK 349 method. All P-PO ${ }_{4}^{-}$concentrations recorded in both seasons, were below 50 $143 \mathrm{mg} \mathrm{L}^{-1}$ and did not interfere with BBSi measurements.

\section{MPB biofilm biomass and key species}

145 Half of the surficial $5 \mathrm{~mm}$ of the sediment from the mini-cores was extracted, weighed 146 (g) and corrected for water content (loss of weight upon drying at $85^{\circ} \mathrm{C}$ for $24 \mathrm{~h}$ ) (see 147 Perkins et al. 2003). Productive biomass via chl a content ( $\mathrm{mg} \mathrm{g}^{-1}$ sed. $d w$.) were 148 determined following the standard method (extraction in methanol; Shwartz \& Lorenzo, 149 1990), with $4 \mathrm{ml}$ of methanol buffered with $\mathrm{MgCO}_{3}$ added to each sediment sample 150 and left at $-4^{\circ} \mathrm{C}$ and in the dark for $24 \mathrm{~h}$. Samples were vortex mixed and centrifuged 151 at $2000 \mathrm{rpm}$ for $15 \mathrm{~min}$. Chl a values were corrected for phaeopigments through 152 acidification following the standard method (Lorenzen, 1966), with absorbance 153 measured at $665 \mathrm{~nm}$ and $750 \mathrm{~nm}$ and repeated following the addition of 1 drop of $10 \%$ $154 \mathrm{HCl}$ to each plastic micro-cuvette.

155 Species composition of the biofilms were determined by filtering approximately $25 \%$ of 
156 the surficial $5 \mathrm{~mm}$ sediments with DI water to remove silts and fine sediment grains.

157 Due to the low biomass, the suspended fractions were placed in petri dishes and

158 diatoms were viewed using bright-field microscopy for the determination of key diatoms

159 species. Individual diatoms were mounted, dried and gold plated for imaging using the

160 Environmental Scanning Electron Microscope (FEI XL30 ESEM FEG).

\section{Chlorophyll fluorescence}

162 Variable chlorophyll fluorescence of undisturbed microalgae assemblages was 163 determined using a Water Pulse Amplitude Modulated (PAM) fluorometer equipped 164 with an EDF/B fibre optic detector (blue light measuring beam and actinic light). The 165 Water PAM $6 \mathrm{~mm}$ diameter Fluid Light Guide fiberoptics probe bundle (that delivered 166 the measuring and saturating light provided by the fluorometer) was applied to the 167 surface of the mudflat perpendicularly, at a fixed distance of $2 \mathrm{~mm}$ and an area of 0.28 $168 \mathrm{~cm}^{2}$. A low frequency, non-actinic measuring beam and a $0.6 \mathrm{~s}$ saturation pulse of $169 \sim 8000 \mu \mathrm{mol} \mathrm{m} \mathrm{m}^{-2} \mathrm{~s}^{-1}$ photosynthetically available radiation (PAR) were used (see Table 1701 for notation). The fluorometer photomultiplier signal gain was set at a level to ensure 171 fluorescence yields of $>300$ units for all measurements (with a new auto zero set each 172 time the gain was altered). The external irradiance levels were logged at each station 173 using the PAM light sensor. All data were stored and downloaded using WinControl-3 174 software.

175 The saturating pulse was applied to the sediments and the operational photosystem II 176 chl fluorescence yield in actinic light $\left(F^{\prime}\right)$ was recorded. The fluorescent parameter $F_{m}$ 177 (in the dark, first step of a rapid light curve) and $F_{m}{ }^{\prime}$ (in the light, subsequent steps of a 178 rapid light curve), the maximum PSII chl fluorescence yield in actinic light when all 179 reaction centres are closed, are often underestimated (see Serôdio et al. 2005) due to 180 retained non-photochemical down regulation in the dark (Perkins et al. 2010). 181 Therefore, the maximum $F_{m}$ value $\left(F_{m}\right.$ max $)$, higher than $F_{m}$, measured under low actinic 182 light, is used for the calculation of associated photophysiological parameters (e.g. $183 \mathrm{NPQ}, \mathrm{F}_{\mathrm{v}} / \mathrm{F}_{\mathrm{m}}$, see below). The maximum quantum efficiency of $\mathrm{PSII}\left(\mathrm{F}_{\mathrm{q}}{ }^{\prime} / \mathrm{F}_{\mathrm{m}}{ }^{\prime}\right)$ was 184 calculated as $\left(F_{m}^{\prime}-F^{\prime}\right) / F_{m}$ '. Rapid Light Curves (RLCs) were produced following 185 Perkins et al. (2006) for the determination of the maximum relative Electron Transport 186 Rate $\left(r E T R_{\max }\right)$, light saturation coefficient $\left(E_{k}\right)$ and the light use coefficient for PSII $(\alpha)$, 187 derived from curve fitting the model of Eilers \& Peeters (1988) using Sigmaplot curve 188 fitter (Systat Software Inc., San Jose). RLCs consisted of the fluorescence responses 189 to nine different actinic irradiances of $20 \mathrm{~s}$ duration. The model consisted of an iterative 190 solution to the curve with 100 iterations processed and significant $(p<0.001)$ 
191 coefficients of $a, b$ and c (Eilers \& Peeters, 1988). Some individual RLCs saturated, 192 with these coefficients used to calculate rETR $\max$ and $\alpha$. However, some RLCs failed 193 to saturate, therefore $r E T R_{\max }$ and $E_{k}$ could not be calculated. $r E T R_{\max }$ was hence 194 estimated as the highest value at the end of the RLC and is used here as a proxy for 195 relative primary productivity. a was also calculated as the initial slope of the RLC simply 196 from:-

$197 \alpha=(\Delta r E T R / \triangle P A R)$ over the first two light curve steps.

198 The maximum quantum yield of PSII in the dark-adapted state, used as a proxy for 199 MPB biofilm health/nutrient limitation, $F_{v} / F_{m}$ (Genty et al., 1989) was calculated as:-

$200 \quad F_{\mathrm{v}} / F_{m}=\left(F_{m}^{\prime} \max -F_{o}\right) / F_{m}^{\prime}$ max

201 The fluorescent parameters of $F_{m}{ }^{\prime}$ max and $F_{m}$ ' were used to calculate downregulation of 202 photochemistry (Lavaud, 2007), in the form of non-photochemical quenching (NPQ):$203 N P Q=\left(\left(F_{m}^{\prime} \max ^{\prime}-F_{m}{ }^{\prime}\right) / F_{m}{ }^{\prime}\right)$.

204 Maximum NPQ (NPQ $\left.{ }_{\max }\right)$ was estimated from each light curve based upon the peak $205 \mathrm{NPQ}$ value. Proportional changes of $\mathrm{F}^{\prime}$ and $\mathrm{F}_{\mathrm{m}}$ ' were analysed to determine whether 206 diatoms were vertically migrating or undergoing NPQ reversal/induction (see Perkins 207 et al. 2010).

\section{Statistical analysis}

209 To determine the variability in biofilm mediation of Si between warm and cold periods, 210 the existence of significant difference $(p<0.001)$ between summer and winter sampled 211 periods was tested. Data (BBSi, BDSi, $\mathrm{P}-\mathrm{PO}_{4^{-}}$, chl $a$ and water content) which failed 212 normal distribution (Kolmogorov Smirnov test) and homogeneity of variance (Levene's

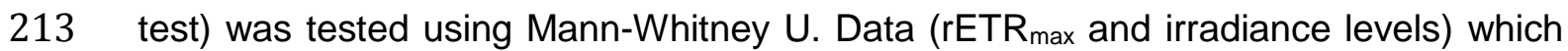
214 had normal distribution (Kolmogorov Smirnov test) and homogeneity of variance 215 (Levene's test) was tested using a Two-tailed Student's t-test. The significant $(p<0.05)$ 216 variability between sites within each season was tested using a Kruskal-Wallis test and 217 one-way ANOVA. The relationship between biological variables and Si was tested, 218 with linear relationships assed using Pearson's correlations.

\section{Results}

\section{BBSi and BDSi intertidal mudflat standing stocks}

220 The Severn Estuary intertidal mudflats had low standing stocks of particulate Si in the

221 form of BBSi during the summer $(0.6 \%)$ and winter $(0.5 \%)$ sampled periods of 2014 222 (Fig. 2), compared to previous benthic Si estuarine studies (e.g. Chou \& Wollast, 2006; 223 Arndt \& Regnier, 2007). BBSi was significantly higher $\left(U_{d f}=362.5, Z=-3.2118, p<0.001\right)$ 
224 under warm conditions compared to cold conditions. BBSi standing stocks were 225 significantly higher during the sampled summer $\left(\mathrm{H}_{(2)}=16.31, p<0.05\right)$ and winter $226\left(\mathrm{H}_{(2)}=23.2, p<0.05\right)$ periods at site 3, nearest to the marine zone, compared to other 227 sampled sites. As a result of local sediment conditions, BBSi varied spatially between 228 the sampled sites, with lower BBSi concentrations at sites 1 (high sand content) 229 compared to high concentrations at site 3 (high mud content), under both warm and 230 cold conditions (Fig. 3). Water content was significantly lower during the warm $231\left(\mathrm{H}_{(2)}=27.73, p<0.001\right)$ and cold $\left(\mathrm{H}_{(2)}=15.07, p<0.001\right)$ periods at Site 1 (exposed and 232 high sand content), compared to site 3 (sheltered and high mud content).

$233 \mathrm{Si}$ in the Severn Estuary was predominantly present in dissolved forms (Fig. 2). BDSi 234 concentrations in the mudflats were significantly greater $\left(U_{d f}=1, Z=-7.2815, p<0.001\right)$ 235 under relatively colder conditions $\left(22.6 \pm 1.0 \mathrm{mg} \mathrm{L}^{-1}\right)$ compared to relatively warm 236 conditions $\left(2.9 \pm 0.5 \mathrm{mg} \mathrm{L}^{-1}\right)$ (Fig. 2). Standing stocks of BDSi was greater at site 3 237 during the warmer summer, with concentrations averaging $4.2 \pm 1.2 \mathrm{mg} \mathrm{L}^{-1}$ compared 238 to site 1 and 2 (av. $2.2 \pm 0.4 \mathrm{mg} \mathrm{L}^{-1}$ ). Under these warm conditions at site 1 , chl a 239 positively correlated with BDSi (Table 3). The highest standing stock of BDSi was 240 recorded at site 1 during the colder winter period, near the mouth of the River Severn, 241 with concentrations averaging $24.7 \pm 1.6 \mathrm{mg} \mathrm{L}^{-1}$, potentially resulting from increased 242 river flow following high rainfall (Fig.2). Furthermore, BDSi positively correlated with 243 chl a during the winter sampled period (Table 3).

$244 \mathrm{P}_{-} \mathrm{PO}_{4}-$ concentrations were greatest during the relatively colder winter period $(0.18 \pm$ $\left.2450.02 \mathrm{mg} \mathrm{L}^{-1}\right)$ compared to the warm summer period $\left(0.16 \pm 0.02 \mathrm{mg} \mathrm{L}^{-1}\right)$ (Fig. 3), but 246 lacked significant variation. $\mathrm{P}_{-} \mathrm{PO}_{4}{ }^{-}$sampled in the summer negatively correlated with

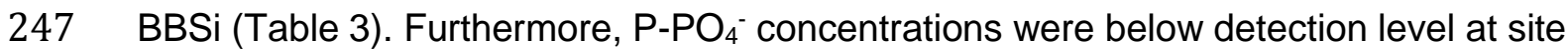
2483 during the summer period (Fig. 3).

\section{Biological mediation of $\mathrm{Si}$}

250 The key diatom taxa observed under seasonal environmental differences were 251 Pleurosigma, Gyrosigma and Nitzschia sigma, similar to the findings presented by 252 Yallop et al. (1994) following an investigation of Portishead mudflats (site 2). Chl a was 253 significantly higher $\left(U_{\mathrm{df}}=176, \mathrm{Z}=-5.3102, p<0.001\right)$ during cold conditions $(240 \pm 23 \mathrm{mg}$ $254 \mathrm{~g}^{-1}$ sed. $d w$.) compared to warm conditions (132 $\pm 19 \mathrm{mg} \mathrm{g}^{-1}$ sed. $d w$.), with average air 255 temperatures having declined by $10.1^{\circ} \mathrm{C}$ (Fig. 2). Biofilm chl a sampled during the 256 summer, positively correlated with BBSi (Table 3). Chl a was higher at site 3 compared 
257 to other sampled sites in both periods of the study (Table 2). Furthermore, at site 3, 258 under cold conditions, chl a positively correlated with BBSi (Table 3).

259 Variable chlorophyll fluorescence analysis during both warm and cold conditions was 260 measured over periods of approximately $3 \mathrm{hrs}$, with both photoperiods subject to high 261 irradiance levels, with peak values of $1278 \mu \mathrm{mol}$ photons $\mathrm{s}^{-1} \mathrm{~m}^{-2}$ (summer) and 1944 $262 \mu \mathrm{mol}$ photons $\mathrm{s}^{-1} \mathrm{~m}^{-2}$ (winter). Diatoms exposed to warmer conditions were significantly 263 more productive $(\mathrm{t}(\mathrm{df})=5.6104, p<0.001)$ compared to diatoms exposed to colder 264 conditions, with $\mathrm{rETR}_{\max }$ averaging $254.1 \pm 20.1$ and $116.0 \pm 27.1$ rel. units, 265 respectively (Table 2), thus increasing the potential for biomineralization of Si under 266 warm conditions (Fig. 2) through enhanced rates of productivity. However, rETR max $_{\text {ax }}$ at 267 site 1, sampled during the summer, negatively correlated with BBSi but positively 268 correlated with BBSi in winter (Table 3). During cold conditions site $3, \mathrm{rETR}_{\max }$ 269 negatively correlated with BBSi (Table 3). Similar to $\mathrm{rETR}_{\max }$, $\alpha$ was higher during 270 warmer conditions compared to cold conditions $(0.22 \pm 0.1$ and $0.18 \pm 0.02 \mu \mathrm{mol}$ 271 photons $\mathrm{s}^{-1} \mathrm{~m}^{-2}$, respectively).

272 During both warm and cold periods, a high proportion of RLCs failed to saturate, 273 probably due to downward migration of cells away from the fluorometer light source as 274 light intensity increased (Fig. 4). In the summer sampling period, 94\% of light curves 275 did not saturate, decreasing to $58 \%$ in the winter, suggesting a greater level of cell 276 movement under warm conditions. $F_{v} / F_{m}(0.65 \pm 0.08$ and $0.44 \pm 0.2$ rel. units $)$ and $277 F_{m \max }(2894 \pm 614$ and $1946 \pm 272$ rel. units) were higher under cold conditions 278 compared to the warmer ones, respectively (Table 2). However, the high irradiance 279 levels recorded during the winter sampling period, despite lower sunshine hours, 280 resulted in down regulation of both $\alpha$ and $\mathrm{rETR}_{\max }$, which implies reduced productivity 281 and hence reduced biomineralization of Si (Fig. 2).

282 As a response to high irradiance levels, the MPB biofilms performed both behavioural 283 and physiological downregulation in order to maximise photosynthesis. Biofilms 284 sampled during the summer were characterised by a migrational system (Fig. 4 and 285 5). Diatoms used downward cell movement away from increasing light levels during 286 the RLCs, increasing $F_{q}^{\prime} / F_{m}^{\prime}$ (Fig. 5). Additionally, as light levels increased there was a 287 rise in $\mathrm{F}_{\mathrm{m}}$ and $\mathrm{F}^{\prime}$, indicating $\mathrm{NPQ}$ reversal alongside downward migration, causing a 288 decrease in these fluorescence yields. As NPQ would be induced with increasing light 289 levels, and $Q_{A}$ would become reduced (both processes acting to reduce yields in the 290 case of $\left.F^{\prime}\right)$, these data ( $F^{\prime}$ and $F_{m}$ ' yields, NPQ data, Fig. 5) suggest downward vertical 
291 cell movement, supporting this to be the cause for the lack of saturation of RLCs (see 292 above). It should be noted that, NPQ, sampled during the summer, positively 293 correlated with BBSi (Table 3), suggesting that these migratory biofilms were 294 sufficiently productive (higher $\mathrm{rETR}_{\max }$ and a compared to the sampled winter) to 295 mediate BBSi, despite having lower biomass.

296 Biofilms sampled during the winter were characterised by high NPQ induction as a 297 response to high irradiance, with reduced migration of the biofilms (Fig. 4 and 5), and 298 hence a larger proportion of RLCs saturated. Residual NPQ was observed at site 2 299 and 3 (Fig. 5) at the beginning of the RLCs. With increasing PAR, F ${ }_{m}$ 'declined, and 300 NPQ and F' increased (Fig. 5), suggesting NPQ induction was greater, and downward 301 cell movement was reduced, compared to the summer. A lack of downward migration 302 was also supported by the larger decrease in $\mathrm{F}_{\mathrm{q}}{ }^{\prime} / \mathrm{F}_{\mathrm{m}}$ ' with increasing PAR increments 303 (Fig. 5). Furthermore, NPQ $Q_{\max }$ sampled during the winter was higher compared to that 304 sampled during summer $(0.8 \pm 0.5$ and $0.19 \pm 0.1$ rel. units, respectively) and NPQ 305 positively correlated with rETR $\max$ (Table 3).

\section{Discussion}

307 Microphytobenthos (MPB) biofilms under warmer summer conditions had lower 308 biomass, and biologically mediated Si through the ecological function of the productive, 309 high light acclimated diatoms that were highly motile during fluorescence 310 measurements. This migratory behaviour increased the potential for growth and 311 the formation of biofilms, which initiated the build-up of BBSi. Biofilms subject to colder 312 winter conditions, had higher relative biomass but of low light acclimated diatoms, 313 which had reduced migratory capabilities and induced NPQ throughout the 314 photoperiod. Through the reduced rates of productivity the potential for 315 biomineralization of $\mathrm{Si}$ may have been reduced. However, despite the high 316 photosynthetic abilities of the diatoms, and regardless of different temperature 317 regimes, the biological mediation of BBSi was low, with poor BDSi uptake, typical of 318 biofilms in a dynamic intertidal estuary subject to high re-suspension and tidal 319 influences. These dynamics resulted in low mudflat BBSi standing stocks, with 320 estuarine Si dominated by dissolved forms, especially during cold periods with 321 increased rainfall. In summary, environmental conditions influenced the diatom322 dominated MPB biofilm biological mediation of Si, preventing sufficient accumulation 323 of BBSi in the intertidal mudflats of the Severn Estuary. Therefore, BBSi and BDSi 
concentrations were best explained by complex hydrodynamics, dissolution kinetics and terrestrial/coastal inputs rather than the biological uptake of $\mathrm{Si}$.

\section{BBSi and BDSi in the Severn Estuary}

Low BBSi standing stocks in the intertidal mudflats were observed during the summer $(0.6 \%)$ and winter $(0.5 \%)$ sampled periods (Fig. 2). The Severn Estuary may have a low BBSi retention throughout the year (Fig. 6), similar to previous benthic Si estuarine studies (Ragueneau et al. 1994; Arndt \& Regnier, 2007; Arndt et al. 2007; Jacobs, 2009; Laurelle et al. 2009; Carbonnel et al. 2009; 2013; Raimonet et al. 2013). For example, Chou \& Wollast (2006) report low BBSi standing stocks in the Scheldt between $0.05 \%$ and $1.5 \%$. Estuarine BSi and BBSi budgets are often low due to the hydro-geomorphological processes enhancing turbidity, leading to a reduction in the abundance of photosynthetic diatoms (Tréguer \& De La Rocha, 2013). However, the high BDSi standing stocks (Fig. 2) suggest that the estuary can be considered as an efficient filter for DSi and may have a significant importance regarding Si cycling.

The spatial distribution of BBSi between the three sites (Fig. 6) reflected three processes; (1) settlement and biological accumulation of particulates relative to the estuarine hydrodynamics, inducing the retention of $\mathrm{Si}$ in more sheltered locations, (2) transportation of particulates as suspended material downstream, and (3) dissolution at biological timescales. Sediment dynamics were likely different at each sampled site.

343 For example, the exposed mudflats at site 1 likely experienced high rates of erosion and re-suspension, which reduced BBSi standing stocks (Fig. 3), whereas the sheltered mudflats from the prevailing south westerly winds at site 3 had increased deposition, inducing the build-up of biofilms, and subsequently BBSi (Fig. 3). However, the overall low standing stocks of BBSi (Fig. 2) suggests the overall high rates of resuspension in the estuary (Manning et al. 2010), preventing the settling and accumulation of particulates in the high water content intertidal mudflats (Table 2), coinciding with the hyper-tidal regime (Neill \& Couch, 2011), were the most likely candidates to explain the observed variations in BBSi. This increased transport of BBSi

352 to the pelagic zone may support high primary productivity in the marine zone of the 353 Outer Bristol Channel (Morris, 1984).

354 The combination of high suspended particulate matter (SPM) and turbidity maxima,

355 further explain the low mudflat BBSi concentrations. Sediment dynamics have 356 previously been investigated for the Severn Estuary (Allen, 1990; Duquesne et al. 2006; Jonas \& Millward, 2010). Manning et al. (2010) report of a turbidity maximum, 
where SPM concentrations were in excess of $10 \mathrm{~g} \mathrm{~L}^{-1}$ in the upper estuary near site 2, which may have reduced $\mathrm{chl}$ a (Table 2) and subsequently BBSi (Fig. 3). The contribution of BBSi from the re-suspended sediments to the overall estuarine BSi budget remains unknown. Previous studies have estimated between $20 \%$ and $40 \%$ of biofilms are re-suspended (de Jonge \& van Beusekom, 1992, 1995; Hanlon et al. 2006). Considering the expected high re-suspension rates and sediment loads, along with the pelagic fraction of BSi, which is expected to be small (Underwood, 2010), the overall estuarine system is unlikely to have a significant retention of $\mathrm{BSi}$, despite potentially high terrestrial inputs of $\mathrm{Si}$ (e.g. DeMaster, 1981; Muylaert \& Raine, 1999). However, a large variation in BBSi resuspension would be expected between spring and neap tides. For example, Parker \& Kirby (1981) report 70\% of the sediment placed into suspension on a spring tide is settled on a neap tide.

Dissolution kinetics may also explain the variations in Si between the three sampled sites (Fig. 3), where particulates were transported downstream, gradually dissolving, increasing BDSi concentrations (e.g. De'Elia et al. 1983; Yamada \& De'Elia 1984). Spatial variations in nitrate, ammonium, phosphate and silicate have previously been shown in the estuary between the freshwaters end members (av. 2.7\%) to the marine end members (av. 28.3\%) (Underwood, 2010). Similarly, in the Bay of Brest (Beucher et al. 2004) and in Chesapeake Bay (De'Elia et al. 1983), BSi dissolution increased DSi retention to $48 \%$ and $65 \%$, respectively. The Severn Estuary may exhibit similar characteristics to the Oder Estuary, including (1) higher export of Si compared to retention, (2) BBSi dissolution resulting in high BDSi retention, and (3) Si fractions dominated by dissolved forms. For example, Pastaszuak et al. (2008) suggests the Oder Estuary behaved as a source of DSi through the dissolution of $\sim 50 \%$ of BSi into $\mathrm{DSi}$, with $25 \%$ of BSi transported to a nearby Bay.

Terrestrial discharge was likely the primary environmental factor influencing the distribution and concentration of $\mathrm{Si}$, and likely influenced the biofilm biological mediation of Si. For example, at the mouth of the River Severn (site 1), the highest standing stock of BDSi was recorded with concentrations averaging $24.7 \pm 1.6 \mathrm{mg} \mathrm{L}^{-1}$, which correlated with high chl a content (Table 3). However, Morris (1984) note the River Severn only supplies a quarter of the freshwater into the estuary. Dissolution of Si may have been less significant compared to terrestrial inputs, especially during the cold winter season (Fig. 2). For example, dissolution in the Scheldt Estuary was of minor importance $(3.6 \%)$ compared to the riverine influx of DSi $\left(5.9 \times 10^{7} \mathrm{~mol}\right)$ (Arndt \& Regnier, 2007). Terrestrial inputs likely resulted in high BDSi concentrations (Fig. 2), 
393

394

395

396

397

398

399

400

401

402

403

404

405

406

407

408

409

410

411

412

413

414

415

416

417

especially during the winter following high rainfall in the Severn Estuary catchment area (273. 5 mm; Met Office, 2015) (Fig. 2). High winter Si concentrations have previously been recorded for the estuary (Morris, 1984). In contrast, during the summer, lower rainfall (103.8 mm; Met Office, 2015) (Fig. 2) alongside peak biological activity (Table 2), likely reduced BDSi standing stocks, and led to a rise in BBSi (Fig. 2).

Terrestrial inputs may also have increased the supply of detrital BSi (BSi $i_{\text {det }}$ ), e.g. phytoliths (Conley, 2002). For example, saltmarshes and wetlands have been shown (Norris \& Hackney, 1999) to have significant in situ accumulation of phytolith BSi. BSidet originating from these habitats may have been responsible for significantly $(p<0.001)$ higher BBSi concentrations (Fig. 3) and chl a contents (Table 2), and the significant correlations between chl $a$ and $\mathrm{rETR}_{\max }$ with BBSi at site 3 (Table 3). Furthermore, $\mathrm{BSi}_{\text {det }}$ from the river and saltmarshes may have contributed as a source of BDSi via remineralization through pore and groundwater discharge by advective transport at high tide, and seepage at low tide (Georg et al. 2009), with phytolith dissolution proven to double DSi inputs compared to dissolution from silicate mineral weathering (Struyf et al. 2005).

\section{Biological mediation of $\mathbf{S i}$}

MPB biomass and productivity

MPB biomass exhibited a significant $(p<0.001)$ difference between warmer summer conditions (13.2 $\mathrm{mg} \mathrm{g}^{-1}$ sed. $d w$.) and colder winter conditions (24.0 $\mathrm{mg} \mathrm{g}^{-1}$ sed. $d w$.) (Table 2). The low winter temperatures (Fig. 2) may have reduced diatom metabolism and/or inhibited cell movement through extracellular polymers (EPS), restricting diatoms ability to vertically migrate away from the fluorometer light source as light intensity increased, subsequently increasing the cell biomass in the surficial $5 \mathrm{~mm}$.

Biomass was high compared to previous estuarine studies (e.g. Underwood \& Kromkamp, 1999) and previous studies on the Severn Estuary (e.g. Underwood \& Paterson, 1993; Yallop \& Paterson, 1994) possibly reflecting increased cohesivity (enhanced by biostabilization), and favourable conditions necessary for benthic growth. Therefore, sites with high water content, e.g. site 2 in the sampled winter (Table 2), may have increased re-suspension rates, reducing the biofilm biomass and accumulation of BBSi (Fig. 3). However, during a tidal emersion period where sediments undergo desiccation due to de-watering, sediment of a lower water content may actually exhibit lower chl a content per unit weight of sediment due to an increase 
in sediment bulk density, emphasising the importance to incorporate changes in water

428 content into the calculation of chl a content (see Perkins et al. 2003). The change in

429 sediment cohesivity between the summer and winter sampling periods likely influenced

430 the variation in biofilm relative primary productivity. The biofilms sampled during the

431 summer had high water content, and were highly productive with relative primary

432 productivity averaging highs of $254.1 \pm 20.1$ rel. units, despite having lower biomass.

433 In comparison, biofilms sampled during the colder winter period were of a lower water

434 content, and had reduced rates of relative primary productivity (116.0 \pm 27.1 rel. units),

435 despite higher biomass (Table 2). However, the complex hydrodynamics most likely

436 resulted in a constant turnover of the thin, unstable biofilms (Yallop et al. 1994), in line

437 with an active transient biofilm that reduced the ecological potential to accumulate

438 BBSi (Fig. 2). Chl a positively correlated with BBSi, consistent with a decline in BBSi

439 concentrations corresponding to reduced biomass of the diatom-dominated biofilms

440 (Table 3).

441 The study assumed the measured chl a was unique to diatoms, however it was 442 possible that $\mathrm{BSi}_{\text {det }}$ and higher abundances of green algae, euglenophytes and 443 cyanobateria (Oppeneheim, 1998, 1991; Underwood, 1994) may have influenced chl $444 \quad a$ and BBSi measurements. Previous studies (Oppenheim, 1988, 1991) have shown a 445 total of 65 taxa, with MPB composition primarily of $N$. vacilla, Navicula viridula var. 446 rostellata, N. humerosa and Diploneis littoralis. Furthermore, diatoms having greater 447 migratory behaviours, for example the observed Pleurosigma, may have reduced the 448 surficial biomass and the biofilms rates of productivity (Cartaxana et al. 2011).

Photosynthetic ability of MPB biofilms

450 Biofilms subject to warmer summer conditions were significantly $(p<0.001)$ more 451 productive and efficient compared to those subject to colder winter conditions, and 452 exhibited strong migratory behaviour (Fig. 5). This behaviour has previously been 453 observed in diatom-dominated biofilms (Perkins et al. 2010). MPB sampled during the 454 summer exhibited higher $\alpha$ and $r^{2} T_{R_{\max }}\left(\right.$ Table 2) with data $\left(F^{\prime}, F_{m}\right.$ yields, and NPQ, 455 Fig. 5) suggesting downward migration was dominant, causing the lack of RLC 456 saturation (Fig. 4). Indeed, 94\% of the RLCs did not saturate. As a result of the 457 enhanced rates of productivity there was greater biological mediation of Si and higher 458 BBSi mudflat standing stocks in the sampled summer period (Fig. 2). A lack of RLC 459 saturation on natural samples has previously been measured (Kromkamp et al. 1998; 460 Perkins et al. 2002; 2010a). Comparative studies (Perkins et al. 2002; 2010b; Serôdio 
461 et al. 2006a; 2008) have also shown migration to follow NPQ induction as diatoms 462 acclimate to increasing light levels.

463 Diatoms sampled during the warmer summer period were relatively nutrient limited, 464 with low $F_{v} / F_{m}$ recorded at all sample sites (Table 2), correlating with BBSi (Table 3). 465 For example, $\mathrm{P}_{-} \mathrm{PO}_{4}{ }^{-}$was below the detection level at site 3 (Fig. 3). However, $\mathrm{P}_{-} \mathrm{PO}_{4}{ }^{-}$ 466 negatively correlated with BBSi (Table 3), suggesting at high $\mathrm{P}_{-} \mathrm{PO}_{4}{ }^{-}$concentrations, 467 BDSi became limiting, potentially as a result of peak summer biological activity. Low 468 standing stocks of BDSi have also been recorded in the Oder Estuary during peak 469 diatom activity in the spring and summer, alongside low DSi riverine loads (which 470 neared $0 \mu \mathrm{mol} \mathrm{dm}{ }^{-3}$ ) (Pastuszak et al. 2008).

471 The significant $(p<0.001)$ difference between biofilm productivity measured during the 472 summer and winter sampled periods was best explained by higher peak irradiance 473 levels experienced during the winter photoperiod, resulting in downregulation (mainly 474 in the form of NPQ induction) of both $\alpha$ and $r E T R_{\max }$ (Table 2) which led to reduced 475 productivity and the reduced biological mediation of Si. NPQ $Q_{\max }$ was higher during cold 476 conditions ( $0.8 \pm 0.5$ rel. units) compared to warmer ones ( $0.2 \pm 0.07$ rel. units) and 477 considered in line with typical $N P Q_{\max }$ values below 4.0 rel. units (Serôdio et al. 2005). 478 Furthermore, NPQ positively correlated with $\mathrm{rETR}_{\max }$ (Table 3), suggesting NPQ 479 induction likely influenced winter productivity. Diatoms sampled during the colder 480 winter period were not nutrient limited (high $F_{v} / F_{m}$ ), but were acclimated to low light 481 and had restricted migrational activity. This contributed to the large reduction in $\mathrm{F}_{\mathrm{q}}{ }^{\prime} / \mathrm{F}_{\mathrm{m}}{ }^{\prime}$ 482 with increasing PAR, and resulted in a higher proportion (42\%) of RLCs saturating 483 (compared to 6\% in summer), e.g. at site 2 and 3 (Fig. 4). Therefore, temperature was 484 likely a key factor in determining the balance between behavioural and physiological 485 down regulation of photochemistry. However, inflections in RLCs (see Perkins et al., 486 2001) were observed during the winter at site 2 and 3, between irradiance levels of 487 579-803 and 283-411 $\mathrm{mmol}$ photons $\mathrm{s}^{-1} \mathrm{~m}^{-2}$, respectively (Fig. 4). These S-shaped 488 curves have occasionally been observed in in situ measurements of intact sediment 489 (Perkins et al. 2002) and suggest vertical migration. Further, the large difference in 490 PAR at which the inflections occurred may have also resulted from different diatom 491 communities present. 


\section{Conclusions}

493 The extensive intertidal mudflats of the hypertidal Severn Estuary are an ideal study

494 areas to carry out a multidisciplinary analysis of $\mathrm{Si}$, allowing for a comprehensive 495 examination of estuarine internal Si cycling. Here we show environmental factors to 496 influence the diatom-dominated biofilms ability to mediate Si. BBSi standing stocks in 497 the mudflats were low compared to other European estuaries. Dissolved Si forms 498 dominated the estuary, with BDSi concentrations reflecting both biological mediation 499 with near complete consumption during the warmer summer conditions, as well as 500 terrestrial/coastal inputs. Biofilms subject to warmer conditions biologically mediated 501 Si by the productive, low biomass of high light acclimated diatoms that were highly 502 motile during fluorescence measurements. This migratory behaviour, despite nutrient 503 limitation, increased the potential for growth and the accumulation of BBSi. Biofilms 504 subject to colder winter conditions of a higher relative biomass of low light acclimated diatoms, had reduced migratory capabilities and induced NPQ throughout the photoperiod. The potential for biomineralization of Si was scaled down as a result of lower rates of productivity under colder winter conditions. We conclude that

508 temperature was an important driver of biofilm productivity. However, despite the high 509 photosynthetic abilities of the diatoms, the biological mediation of BBSi was considered 510 low during both sampled periods. BBSi and BDSi concentrations were best explained 511 by complex hydrodynamics increasing biofilm re-suspension, dissolution kinetics and 512 terrestrial/coastal inputs rather than the biological uptake of Si. However, the estuaries 513 importance for Si cycling on a wider geographical scale, considering the high BDSi 514 standing stocks, high rates of re-suspended BBSi and all external inputs of $\mathrm{Si}$, requires 515 further work into, 1) the benthic-pelagic coupling, 2) transportation of Si and nutrients 516 along the tidal river, estuary and coastal zone, and 3) the influence of the complex tidal 517 regime and sediment dynamics (through re-suspension and mineralization) on Si over 518 spatial and temporal scales.

\section{Acknowledgments}

520 The project was developed as part of an Integrated Masters in Marine Geoscience at 521 Cardiff University School of Earth and Ocean Science. We acknowledge the role of J. 522 Pinnion (Cardiff University) and G. Wallington for their fieldwork assistance, and L. Axe 523 (Cardiff University) who assisted with the SEM analysis. We would also like to thank 524 Natural Resource Wales and Newport Wetland Reserve for their assistance in the 525 project. We thank the two anonymous reviewers for their constructive comments and help in improving the manuscript. 


\section{References}

Allen, J. 1990. The Severn Estuary in southwest Britain: its retreat under marine transgression, and fine-sediment regime. Sedimentary Geology. 66:13-28.

Arndt, S., Regnier, P. 2007. A model for the benthic-pelagic coupling of silica in estuarine ecosystems: sensitivity analysis and system scale simulation. Biogeosciences. 4:331-352.

Arndt, S., Vanderborght, J., Regnier, P. 2007. Diatom growth response to physical forcing in a macrotidal estuary: Coupling hydrodynamics, sediment transport, and biogeochemistry. J. Geophys. Res. 112.

Aure, J., Danielssen, D., Svendsen, E. 1998. The origin of Skagerrak coastal water off Arendal in relation to variations in nutrient concentrations. ICES J. Mar. Sci. 55:610 - 619.

Beucher, C., Tréguer, P., Corvaisier, R., Hapette, A., Elskens, M. 2004. Production and dissolution of biosilica, and changing microphytoplankton dominance in the Bay of Brest (France). Mar Ecol Prog Ser. 267:57-69.

Brzezinski, M., Villareal, T., Lipschultz, F. 1998. Silica production and the contribution of diatoms to new and primary production in the Central North Pacific. Mar. Ecol.: Prog. Ser. 167:89-104.

Carbonnel, V., Lionard, L., Muylaert, K., Chou, L. 2009. Dynamics of dissolved and biogenic silica in the freshwater reaches of a macrotidal estuary (The Scheldt, Belgium). Biogeochemistry. 96:49-72.

Carbonnel, V., Vanderborght, J., Chou, L. 2013. Silica Mass-Balance and Retention in the Riverine and Estuarine Scheldt Tidal System (Belgium/The Netherlands). Aquatic Geochemistry. 19:501-516.

Cartaxana, P., Ruivo, M., Hubas, C., Davidson, I., Serôdio, J., Jesus, B. 2011. Physiological verses behavioural photoprotection in intertidal epipelic and epipsamic benthic diatom communities. Journal of Experimental Marine Biology Ecology. 405:120-127.

Conley, D., Malone, T. 1992. Annual cycle of dissolved silicate in Chesapeake Bay: implications for the production and fate of phytoplankton biomass. Marine Ecology Progress Series. 81:121-128.

Conley, D. 2002. Terrestrial ecosystems and the global biogeochemical silica cycle. Global Biogeochemical Cycles. 16(4):68-75.

Correll, D., Jordan, T., Weller, D. 2000. Dissolved silicate dynamics of the Rhode river watershed and estuary. Estuaries. 23:188-198.

Chou, L., Wollast, R. 2006. Estuarine silicon dynamics, in: The Silicon Cycle: Human Perturbations and Impacts on Aquatic Systems, edited by: Ittekkot, D., Unger, C., Humborg, C., and Tac An. Island Press, Washington, Covelo, London. 66:93-120.

DeMaster, D. 1981. The supply and accumulation of silica in the marine environment. Geochimica et Cosmochimica Acta. 45:1715-1732.

De'Elia, C., Nelson, D., Bonton, W. 1983. Chesapeake Bay nutrient and plankton dynamics: III. The annual cycle of dissolved silicon. Geochim Cosmochim Acta. 47:1945-1955.

de Jonge, V., van Beusekom, J. 1992. Contributions of re-suspended microphytobenthos to total phytoplankton in the Ems estuary and its possible role for grazers. Netherlands Journal of Sea Research. 30:91-105.

de Jonge, V., van Beusekom, J. 1995. Wind- and tide-induced resuspension of sediment microphytobenthos from the tidal flats in the Ems estuary. Limnology and Oceanography. 40:766-778.

Duquesne, S., Newton, L., Giusti, L., Marriott, S., Stark, H., Bird, D. 2006. Evidence for declining levels of heavy-metals in the Severn Estuary and Bristol Channel, UK and their spatial distribution in sediments. Environmental Pollution. 143:187-196. 
Eilers, P., Peeters, J. 1988. A model for the relationship between light intensity and the rate of photosynthesis in phytoplankton. Ecological Modelling. 42:199-215.

Fortner, S.,Lyons, W., Carey, A., Shipitalo, M., Welch, S., Welch, K. 2012. Silicate weathering and $\mathrm{CO}_{2}$ consumption within agricultural landscapes, the OhioTennessee River Basin, USA S. K. Biogeosciences. 9:941-955.

Genty, B., Briantais, J., Baker, N. 1989. The relationship between the quantum yield of photosynthetic electron transport and quenching of chlorophyll fluorescence. Biochimica et Biophysica Acta. 990:87-92.

Georg, R., West, A., Basu, A., Halliday, A. 2009. Silicon fluxes and isotope composition of direct groundwater discharge into the Bay of Bengal and the effect on the global ocean silicon isotope budget. Earth and Planetary Science Letters. 283:67-74.

Gilpin, L., Davidson, K., Roberts, E. 2004. The influence of changes in nitrogen: silicon ratios on diatom growth dynamics. Journal of Sea Research. 51:21-35.

Hammer, O., Harper, D., Ryan, P. 2001. PAST: Paleontological statistics software package for education and data analysis. [online] Available in: <http://palaeoelectronica.org/2001_1/past/issue1_01.htm>.

Hanlon, A., Bellinger, B., Haynes, K., Xiāo, G., Hofmann, T., Gretz, M., Ball, A., Osborn, A., Underwood, G. 2006. Dynamics of extracellular polymeric substance (EPS) production and loss in an estuarine, diatom-dominated, microalgal biofilm over a tidal emersion-immersion period. Limnology and Oceanography. 21:79-93.

Hurd, D. 1977. The effects of glacial weathering on silica budget of Antarctica waters. Geochim Cosmochim Acta. 41:1213-1222.

Jacobs, S. 2009. Silica cycling and vegetation development in a restored freshwater tidal marsh. 1-198.

Jesus, B., Perkins, R., Consalvey, M., Brotas, V., Paterson, D. 2006. Effects of vertical migrations by benthic microalgae on fluorescence measurements of photophysiology. Marine Ecology Progress Series.315:55-66.

Jonas, P., Millward, G. 2010. Metals and nutrients in the Severn Estuary and Bristol Channel: contemporary inputs and distributions. Marine Pollution Bulletin. 61(1-3):52-67.

Kromkamp, J., Barranguet, C., Peene, J.1998. Determination of microphytobenthos PSII quantum efficiency and photosynthetic activity by means of variable chlorophyll fluorescence. Marine Ecology Progress Series. 62:45-55.

Kirby, 2010. Distribution, transport and exchnages of fine sediment, with tidal power implications: Severn Estuary, UK. Marine Pollution Bulletin. 61:21-36.

Lavaud, J., Kroth, P. 2006. In diatoms, the transthylakoid proton gradient regulates the photoprotective non-photochemical fluorescence quenching beyond its control on the xanthophyll cycle. Plant Cell Physiology. 47:1010-1016.

Lavaud, J. 2007. Fast regulation of photosynthesis in diatoms: mechanisms, evolution and ecophysiology. Plant Science and Biotechnology. 1:267-287.

Liang, D., Junqiang, X., Falconer, R., Zhang, J. 2013. Study on Tidal Resonance in Severn Estuary and Bristol Channel. Coastal Engineering Journal. 56(1):1-18.

Liu, W., Hsu, M., Chen, S., Wu, C., Kuo, A. 2005. Water column light attenuation Dasnshuei river estuary, Taiwan. Journal of the American Water Resource Association. 425-435.

Liu, S., Ye, X., Zhang, L., Zhang, G., Wu, Y. 2008. The silicon balance in Jiaozhou Bay, North China. J Mar Syst. 74:639-648.

Liu, S., Hong, G., Zhang, J., Ye, X., Jiang, X. 2009. Nutrient budget of large Chinese estuaries. Biogeosciences. 6:2245-2263.

Lorenzen, C. 1966. A method for the continuous measurement of in vivo chlorophyll concentration. Deep-Sea Research. 13: 223-227.

Manning, A., Langston, W., Jonas, P. 2010. A review of sediment dynamics in the Severn Estuary: Influence of flocculation. Marine Pollution Bulletin. 61:37-51. 
Maxwell, K., Johnson, G. 2000. Chlorophyll fluorescence-a practical guide. Journal of Experimental Botany. 51:659-668.

Met Office. 2011. Climate: Observations, projections and impacts. [pdf] Met Office. Available in: <http://www.metoffice.gov.uk/media/pdf/t/r/UK.pdf> [Accessed 2015].

Met Office. 2015. UK climate: download regional values. [pdf] Met Office. Available in: <http://www.metoffice.gov.uk/climate/uk/summaries/datasets> [Accessed 2015].

Moosdorf, N., Hartmann, J., Lauerwald, R. 2011. Changes in dissolved silica mobilization into river systems draining North America until the period 20812100. Journal of Geochemical Exploration. 110(1):31-39.

Morris, R. 1984. The chemistry of the Severn Estuary and the Bristol Channel. Marine Pollution Bulletin. 15(2):57-61.

Muylaert, K., Raine, R. 1999. Import, mortality and accumulation of coastal phytoplankton in a partially mixed estuary (Kinsale harbour, Ireland). Hydrobiologia. 412:53-65.

Norris, A., Hackney, C. 1999. Silica content of a mesohaline tidal marsh in North Carolina. Estuarine Coastal Shelf Science. 49:597-605.

Neill, S., Couch, S. 2011. Impact of Tidal Energy Converter (TEC) array operation on sediment dynamics. Renewable Energy. 37:387-397.

Oppenheim, D. 1988. The distribution of epipelic diatoms along an intertidal shore in relation to principal physical gradients. Botanica Marina. 31:65-72.

Oppenheim, D. 1991. Seasonal changes in epipelic diatoms along an intertidal shore, Berrow flats, Somerset. Journal of the Marine Biological Association of the United Kingdom. 71:579-596.

Parker, W., Kirby, R. 1981. The behaviour of cohesive sediment in the inner Bristol Channel and Severn Estuary in relation to construction of the Severn Barrage (Unpublished). Institute of oceanographic sciences. 117: 1-39.

Pastuszak, M., Conley, D., Humborg, C., Witek, Z., Sitek, S. 2008. Silicon dynamics in the Oder estuary, Baltic Sea. Journal Marine System. 73:250-262.

Perkins, R., Underwood, G., Brotas, V., Snow, G., Jesus, B., Ribeiro, L. 2001. Responses of microphytobenthos to light: primary production and carbohydrate allocation over an emersion period. Marine Ecology Progress Series. 223:10112.

Perkins, R., Oxborough, K., Hanlon, A., Underwood, G., Baker, N. 2002. Can chlorophyll fluorescence be used to estimate the rate of photosynthetic electron transport within microphytobenthic biofilms? Marine Ecology Progress Series. 228:47-56.

Perkins, R., Honeywill, C., Consalvey, M., Paterson, D. 2003. Changes in microphytobenthic chlorophyll $a$ and EPS resulting from sediment compaction due to de-watering: opposing patterns in concentration and content. Continental shelf science. 23(6):575-586.

Perkins, R., Mouget, J., Lefevre, S. 2006. Light response curve methodology and possible implications in the application of chlorophyll fluorescence to benthic diatoms. Marine Biology. 149:703-712.

Perkins, R., Lavaud, J., Mouget, S., Cartaxana, P., Rosa, P., Barille, L., Brotas, V., Jesus, B. 2010a. Vertical cell movement is a primary response of intertidal benthic biofilms to increasing light dose. Marine Ecology Progress Series. 416:93-103.

Perkins, R., Kromkamp, J., Serôdio, J., Lavaud, J., Jesus, B., Mouget, J., Lefebvre, S., Forster, R. 2010b. The application of variable chlorophyll fluorescence to microphytobenthic biofilms. In: Suggett, D., Borowitzka, M., Prášil, O. eds. Chlorophyll a Fluorescence in Aquatic Sciences: Methods and Applications. Developments in Applied Phycology. London: Springer. 4:237275. 
Pickney, J., Zingmark, R. 1991. Effects of tidal stage and sun angles on intertidal benthic microalgae productivity. Marine Ecology progress Series. 76:81-89.

Raimonet, M., Andrieux,L., Ragueneau, O., Michaus, E., Kerouel, R., Philippon, X., Nonent, M., Laurent, M. 2013. Strong gradient of benthic biogeochemical processes along a macrotidal temperate estuary: focus on $\mathrm{P}$ and $\mathrm{Si}$ cycles. Biogeochemistry. 115:399-417.

Ragueneau O, De Blas Varela E, Tréguer P, Quéguiner B, Del Amo Y. 1994. Phytoplankton dynamics in relation to the biogeochemical cycle of silicon in a coastal ecosystem of western Europe. Mar Ecol Prog Ser. 106:157-172.

Ragueneau, O., Tréguer, P., Leynaert, A., Anderson, R., Brzezinski, M., DeMaster, D., Dugdale, R., Dymond, J., Fischer, G., Francois, R., Heinze, C., Maier-Reimer, E., Martin-Jézéquel, V., Nelson, D., Quéguiner, B. 2000. A review of the Si cycle in the modern oceans: recent progress and missing gaps in the application of biogenic opal as a paleoproductivity proxy. Global Planet Change. 26(4): 317-365.

Redfield, A., Ketchum, B., Richards, F. 1963. The influence of organisms on the composition of sea water in the sea. 2:26-77.

Rendell, A, Horrobin, T., Jickells, T., Edmunds, H., Brown, J., Malcom, S. 1997. Nutrient cycling in the Great Ouse estuary and its impact on nutrient fluxes to The Wash, England. Estuar Coast Shelf Sei. 45(5):653-668.

Serôdio, J., Cruz, S., Vieira, S., Brotas, V. 2005. Non-photochemical quenching of chlorophyll fluorescence and operation of the xanthophyll cycle in estuarine microphytobenthos. Journal of Experimental Marine Biology Ecology. 326:157169.

Serôdio, J., Vieira, S., Cruz, S., Coelho, H. 2006a. Rapid light response curves of chlorophyll fluorescence in microalgae: relationship to steady-state light curves and non-photochemical quenching in benthic diatom-dominated assemblages. Photosynthesis Research. 90:29-43.

Serôdio, J., Coelho, H., Vieira, S., Cruz, S. 2006b. Microphytobenthos vertical migratory photoresponse as characterised by light-response curves of surface biomass. Estuarine Coastal and Shelf Science. 68:547-556.

Serôdio, J., Vieira, S., Cruz, S. 2008. Photosynthetic activity, photoprotection and photoinhibition in intertidal microphytobenthos as studied in situ using variable chlorophyll fluorescence. Continental Shelf Research. 28:1363-1375.

Shwartz, S., Lorenzo, T. 1990. Chlorophyll in foods. Food Science and Nutrition. 29(1):1-17.

Smith, D., Underwood, G. 1998. Exopolymer production by intertidal epipelic diatoms. Limnol. Oceanogr. 43(7): 1578-1591.

Struyf, E., Damme, S., Gribsholt, B., Meir, P. 2005. Freshwater marshes as dissolved silica recyclers in an estuarine environment (Schelde estuary, Belgium). Hydrobiologia. 540:69-77.

Teasdale, P., Batley, G., Apte, S., Webster, I. 1995. Pore water sampling with sediment peepers. Trends Anal. Chem. 14:250-256.

Tréguer, P., De La Rocha, C. 2013. The World Ocean Silica Cycle. Marine Science. $5(5.1): 2-25$.

Underwood, G. 1994. Seasonal and spatial variation in epipelic diatom assemblages in the Severn Estuary. Diatom Research. 9:451-472.

Underwood, G., Kromkamp, J. 1999. Primary production by phytoplankton and microphytobenthos in estuaries. Advance in Ecology Press. 29:93-153.

Underwood, G. 2010. Microphytobenthos and phytoplankton in the Severn Estuary, UK: Present situation and possible consequences of a tidal energy barrage. Marine Pollution Bulletin. 61:83-91.

Underwood, G., Paterson, D.1993. Recovery of intertidal benthic diatoms from biocide treatment and associated sediment dynamics. Journal of the Marine Biological Association of the United Kingdom. 73:25-45. 


\section{Figure Captions}

758 Figure 1. Severn Estuary intertidal mudflat study area. Severn Estuary (A) is situated

Figure. 3. Distribution of BDSi and BBSi during the summer (A) and winter (B), and P$\mathrm{PO}_{4}^{-}$concentration $(C)$ in the Severn Estuary from the upper estuary (Severn Beach,

West, A., Galy, A., Bickle, M. 2005. Tectonic and climatic controls on silicate weathering. Earth and Planetary Science Letters. 235:211-228.

Yamada, S., De'Elia, C. 1984. Silicic acid regeneration from estuarine sediment cores. Marine Ecology Progress Series. 18:113-118.

Yallop, M., Winder, B., Paterson, D., Stal, L. 1994. Comparative structure, primary production and biogenic stabilization of cohesive and non-cohesive marine sediments inhabited by microphytobenthos. Estuarine, Coastal and Shelf Science. 39(6):565-582.

Yallop, M., Paterson, D. 1994. Survey of Severn estuary. In: Krumbein, W., Paterson, D., Stal, L.(Eds.), Biostabilization of Sediments. Bibliotheks und Informationssystem der Universität Oldenburg (BIS). Verlag, Oldenburg, pp. 279-326. in the southwest of UK (B). Tidal limit in the River Severn reaches Maisemore, north Gloucester. Outer Severn Estuary limit identified as a transect between Lavernock Point and Sand Point (14 km wide), near Weston-Super-Mare. Mudflats north of Severn Bridge are sandy, whilst lateral banks south of the bridge are predominantly muddy. Estuary discharges into Bristol Channel followed by the Irish Sea and the North Atlantic Ocean. Bathymetry of the Severn Estuary (C). DTM of the coastline around the Severn Estuary (D).

Figure. 2. Standing stocks of BDSi (A) and BBSi (B) in the Severn Estuary intertidal mudflats. Rainfall $(\mathrm{mm})$ for the Severn Estuary catchment area and average air temperature $\left({ }^{\circ} \mathrm{C}\right)$ for the summer and winter sampled months (Met Office, 2015). Error bars are the standard error in the calculation of the average BDSi and BBSi concentration, rainfall and temperature. BBSi: benthic biogenic silica, $n=36$ (summer), $n=35$ (winter). BDSi: benthic dissolved silicon, $n=36$ (summer), $n=36$ (winter). site 1), to the mid-estuary (Portishead, site 2) and the lower mid-estuary (Newport Wetlands, site 3). Error bars are the standard error in the calculation of the average BDSi, BBSi and $\mathrm{P}_{-} \mathrm{PO}_{4}$ concentration. BBSi: benthic biogenic silica, $n=36$ (summer), $n=35$ (winter). BDSi: benthic dissolved silicon, $n=36$ (summer), $n=36$ (winter). $\mathrm{P}^{-} \mathrm{PO}_{4}$ : orthophosphate, $n=36$ (summer), $n=36$ (winter). 
779 Figure. 4. Rapid Light Curves for the summer (A) and winter (B). Downregulation 780 interference (S-shaped) curves in winter RLCs at site 3 (light grey) and site 2 (dark 781 grey).

782 Figure. 5. Diatom photosynthetic activity and downregulation processes. A-C) 783 Summer chlorophyll fluorescence. D-F) Winter chlorophyll fluorescence. A and D) Site 784 1: $n=11, n=10$. B and E) Site 2: $n=11, n=5$. C and F) Site 3: $n=11, n=3$. Chlorophyll 785 fluorescence $\left(F^{\prime}\right.$ and $\left.F_{m}{ }^{\prime}\right)$. $F^{\prime}$ : minimum fluorescence yield in actinic light. $F_{m}$ : maximum 786 fluorescence yield in actinic light. PSIl efficiency $\left(F_{q}{ }^{\prime} / F_{m}{ }^{\prime}\right)$ : maximum photosynthetic 787 efficiency of PSII. NPQ: non-photochemical quenching. PAR: photosynthetically 788 available radiation.

789 Figure. 6. BBSi and BDSi dynamics in the Severn Estuary in the summer (A) and 790 winter (B). Cylinders represent biofilm biomass. Dark arrows represent river sources. 791 Arrows represent export of BBSi (light grey) and BDSi (black) to the coastal zone. 792 BBSi: benthic biogenic silica. BDSi: benthic dissolved silicon.

\section{Table Captions}

794 Table 1. Notations for silicon parameters, nutrients, biomass and chlorophyll 795 fluorescence.

796 Table 2. Microphytobenthos biomass and variable chlorophyll fluorescence 797 parameters. Values reported with standard deviation $\pm S D$. Chl a: chlorophyll a: $798 n=36$ (summer), $n=36$ (winter). $r E T R_{\max }$ : relative maximum Electron Transport Rate: $799 n=34$ (summer), $n=18$ (winter). $\alpha$ : maximum light use coefficient: $n=34$ (summer), $800 n=18$ (winter). $F_{v} / F_{m}$ : ecological health, $n=34$ (summer), $n=27$ (winter). NPQmax: 801 maximum non-photochemical quenching, $n=34$ (summer), $n=17$ (winter). $F_{m}$ : maximum 802 PSII Chl fluorescence yield in actinic light when all reaction centres are closed: $803 n=34$ (summer), $n=27$ (winter). $F_{m}^{\prime}$ : maximum $F_{m}^{\prime}$ value under low actinic light, $804 n=34$ (summer), $n=17$ (winter).

805 Table 3. Key drivers of BBSi and BDSi during the summer and winter in the Severn 806 Estuary. Pearson's correlations reported with coefficient values $(r)$ and number of 807 samples $(n)$. Significant correlations $(p<0.05)$ are shown in bold. BBSi: benthic 808 biogenic silica. BDSi: benthic dissolved silicon. Chl a: chlorophyll a. rETR $\max$ : relative 
809 maximum Electron Transport Rate. $\alpha$ : maximum light use coefficient. $F_{v} / F_{m}$ : ecological 810 health. NPQ: non-photochemical quenching. 

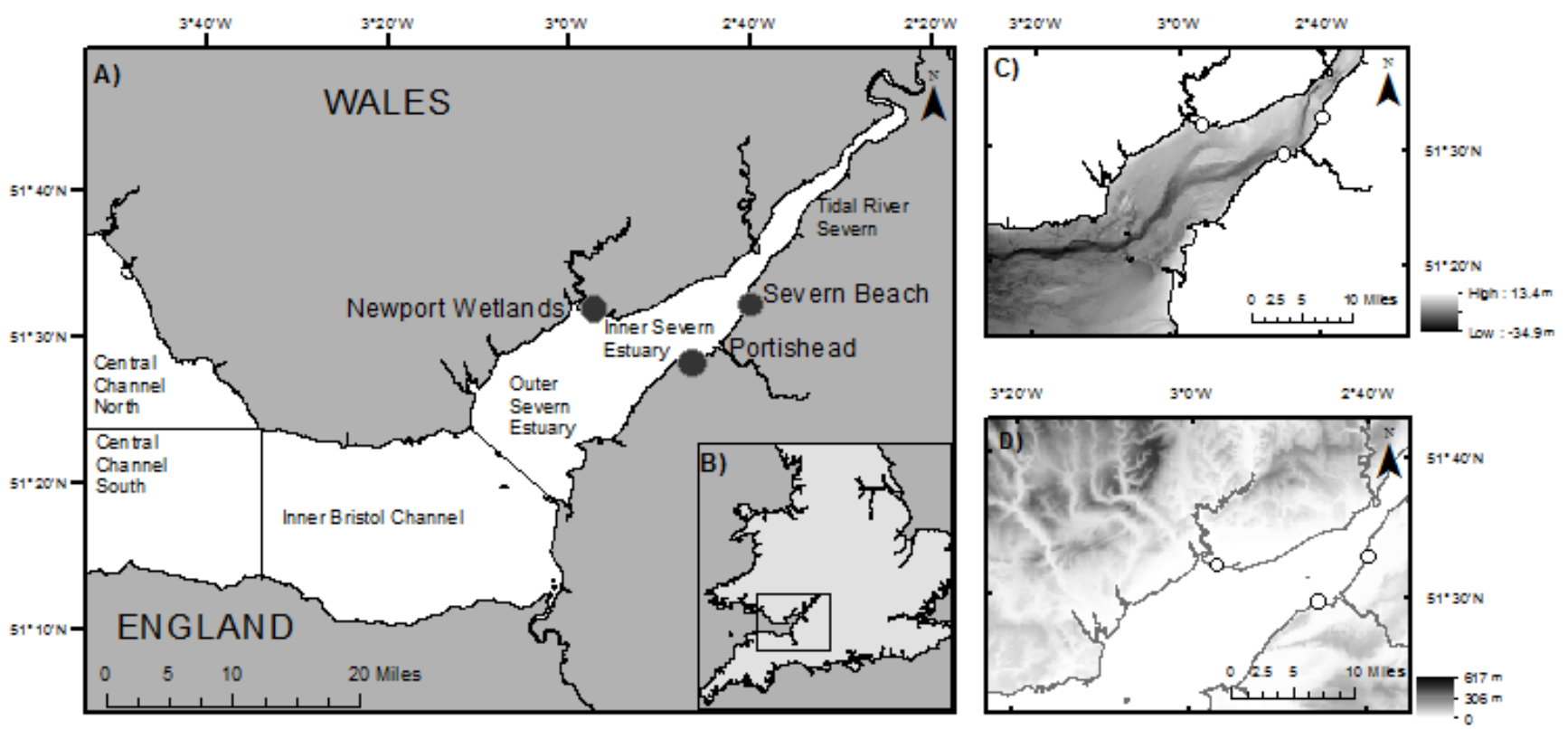


\begin{tabular}{|c|c|}
\hline Parameter & Description \\
\hline $\begin{array}{l}\text { BSi } \\
\text { BBSi } \\
\text { DSi } \\
\text { BDSi }\end{array}$ & $\begin{array}{l}\text { Biogenic silica } \\
\text { Benthic biogenic silica } \\
\text { Dissolved silica } \\
\text { Benthic dissolved silica }\end{array}$ \\
\hline $\mathrm{P}$ & Orthophosphate \\
\hline & $\begin{array}{l}\text { Microphytobenthos } \\
\text { Chlorophyll a (proxy for biomass) }\end{array}$ \\
\hline 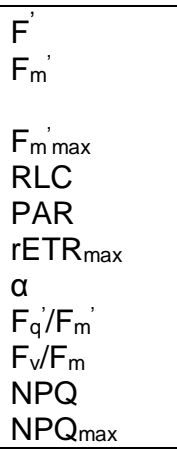 & $\begin{array}{l}\text { Operational PSII Chl fluorescence yield in actinic light } \\
\text { Maximum PSII Chl fluorescence yield in actinic light when all reaction centres are } \\
\text { closed } \\
\text { Maximum Fm } \\
\text { Rapid Light Curve } \\
\text { Photosynthetically available radiation } \\
\text { Relative Maximum Electron Transport Rate } \\
\text { Maximum light use coefficient for PSII } \\
\text { Maximum quantum efficiency of PSII } \\
\text { Maximum photochemical yield (MPB biofilm health) } \\
\text { Non-photochemical quenching } \\
\text { Maximum non-photochemical quenching }\end{array}$ \\
\hline
\end{tabular}




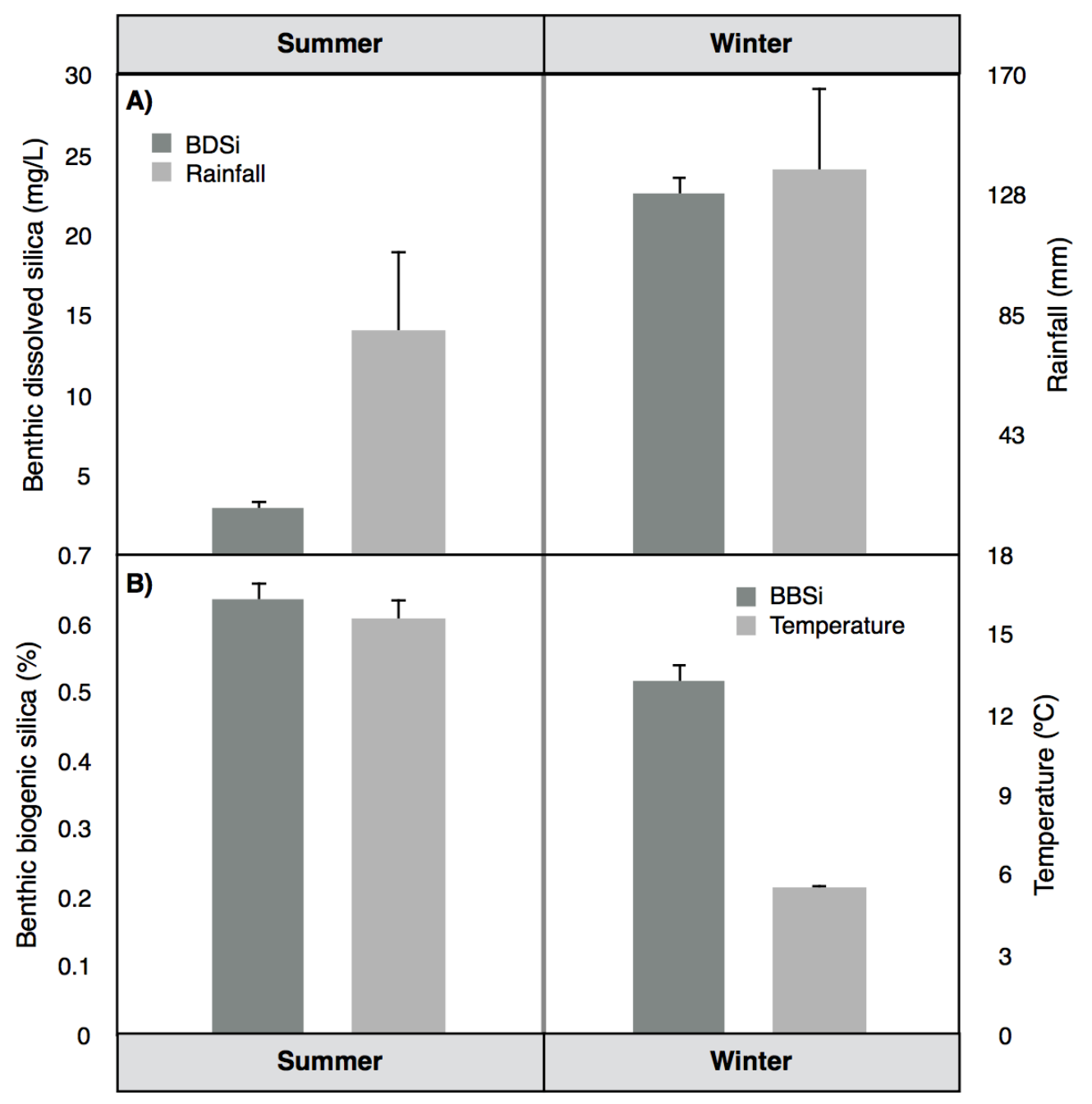




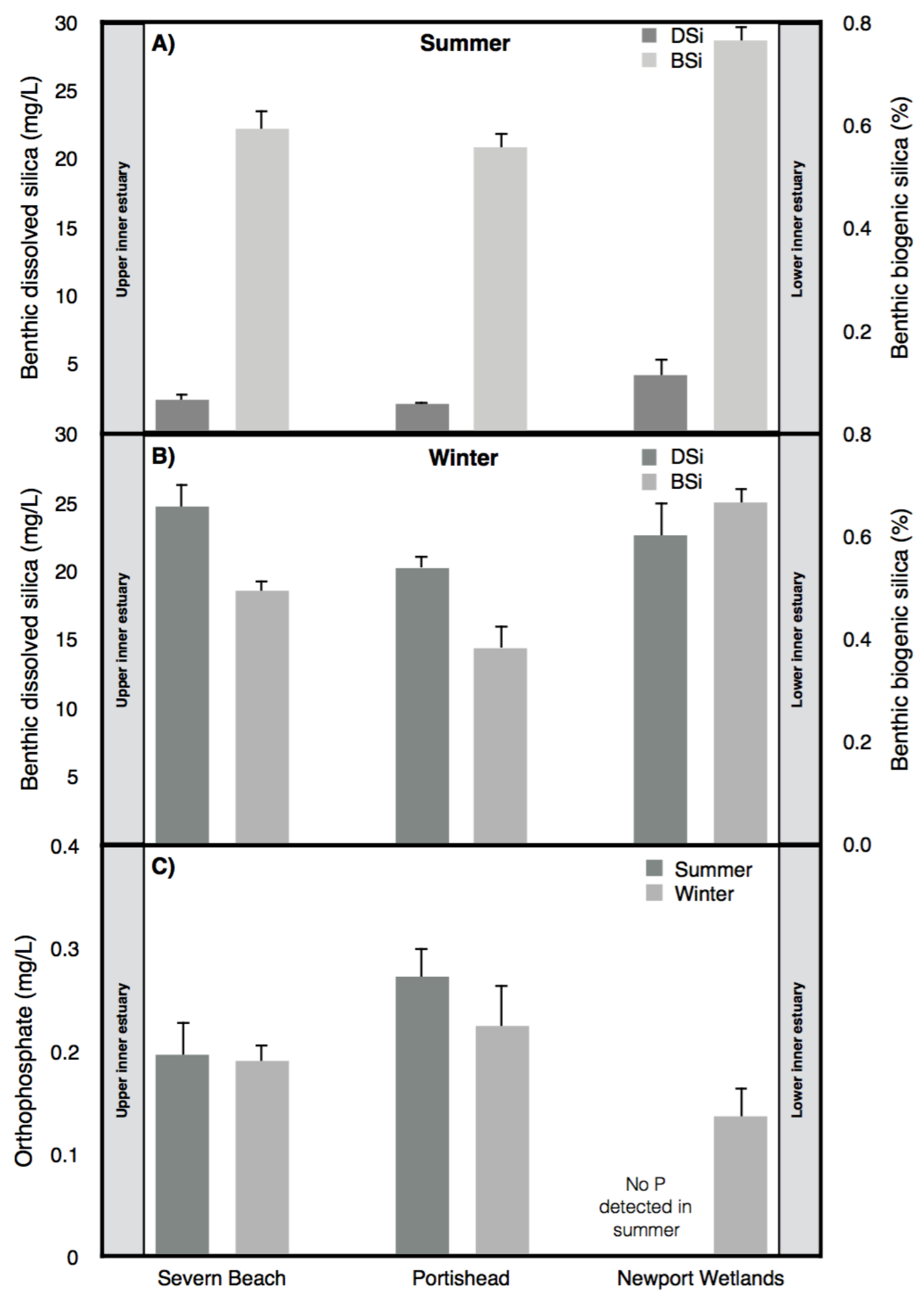




\begin{tabular}{|c|c|c|c|c|c|c|c|c|}
\hline Location & Site & $\begin{array}{l}\text { Chl a (mg g }{ }^{-1} \\
\text { sed. } d w .)\end{array}$ & $\begin{array}{c}\text { Water } \\
\text { content (\%) }\end{array}$ & $\begin{array}{c}\mathrm{rETR}_{\max } \text { (rel. } \\
\text { units) }\end{array}$ & $\begin{array}{c}\alpha(\mu \mathrm{mol} \\
\left.\text { photons } \mathrm{m}^{-2} \mathrm{~s}^{-1}\right)\end{array}$ & $\begin{array}{c}\mathrm{F}_{\mathrm{v}} / \mathrm{F}_{\mathrm{m}} \text { (rel. } \\
\text { units) }\end{array}$ & $\begin{array}{c}\mathrm{NPQ}_{\max } \\
\text { (rel. } \\
\text { units) } \\
\end{array}$ & $\begin{array}{c}F_{m}^{\prime} \max (r e l . \\
\text { units) }\end{array}$ \\
\hline $\begin{array}{l}\text { Summer } \\
\text { Severn Beach }\end{array}$ & 1 & $11.0 \pm 1.9$ & $54.9 \pm 0.4$ & $257.2 \pm 16.9$ & $0.24 \pm 0.02$ & $0.48 \pm 0.5$ & $0.3 \pm 0.03$ & $1713 \pm 180$ \\
\hline Portishead & 2 & $11.3 \pm 2.1$ & $51.8 \pm 0.8$ & $235.2 \pm 27.6$ & $0.23 \pm 0.02$ & $0.47 \pm 0.0$ & $0.12 \pm 0.1$ & $2314 \pm 320$ \\
\hline $\begin{array}{l}\text { Newport } \\
\text { Wetlands }\end{array}$ & 3 & $17.3 \pm 1.7$ & $65.2 \pm 0.6$ & $269.8 \pm 15.9$ & $0.18 \pm 0.03$ & $0.36 \pm 0.1$ & $0.11 \pm 0.1$ & $1813 \pm 332$ \\
\hline Average & & $13.2 \pm 1.9$ & $57.3 \pm 0.6$ & $254.1 \pm 20.1$ & $0.2 \pm 0.02$ & $0.44 \pm 0.2$ & $0.17 \pm 0.1$ & $1946 \pm 277$ \\
\hline $\begin{array}{l}\text { Winter } \\
\text { Severn Beach }\end{array}$ & 1 & $24.5 \pm 2.6$ & $53.2 \pm 0.8$ & $109.7 \pm 21.5$ & $0.10 \pm 0.1$ & $0.65 \pm 0.1$ & $0.17 \pm 0.0$ & $2765 \pm 798$ \\
\hline Portishead & 2 & $21.3 \pm 1.6$ & $57.9 \pm 0.8$ & $97.3 \pm 20.8$ & $0.17 \pm 0.04$ & $0.63 \pm 0.1$ & $0.18 \pm 0.0$ & $3318 \pm 637$ \\
\hline $\begin{array}{l}\text { Newport } \\
\text { Wetlands }\end{array}$ & 3 & $26.0 \pm 2.8$ & $53.8 \pm 0.9$ & $141.0 \pm 39.1$ & $0.20 \pm 0.01$ & $0.67 \pm 0.0$ & $1.3 \pm 0.78$ & $2601 \pm 408$ \\
\hline Average & & $24.0 \pm 2.3$ & $55.0 \pm 0.8$ & $116.0 \pm 27.1$ & $0.16 \pm 0.05$ & $0.65 \pm 0.1$ & $0.84 \pm 0.4$ & $2894 \pm 614$ \\
\hline
\end{tabular}



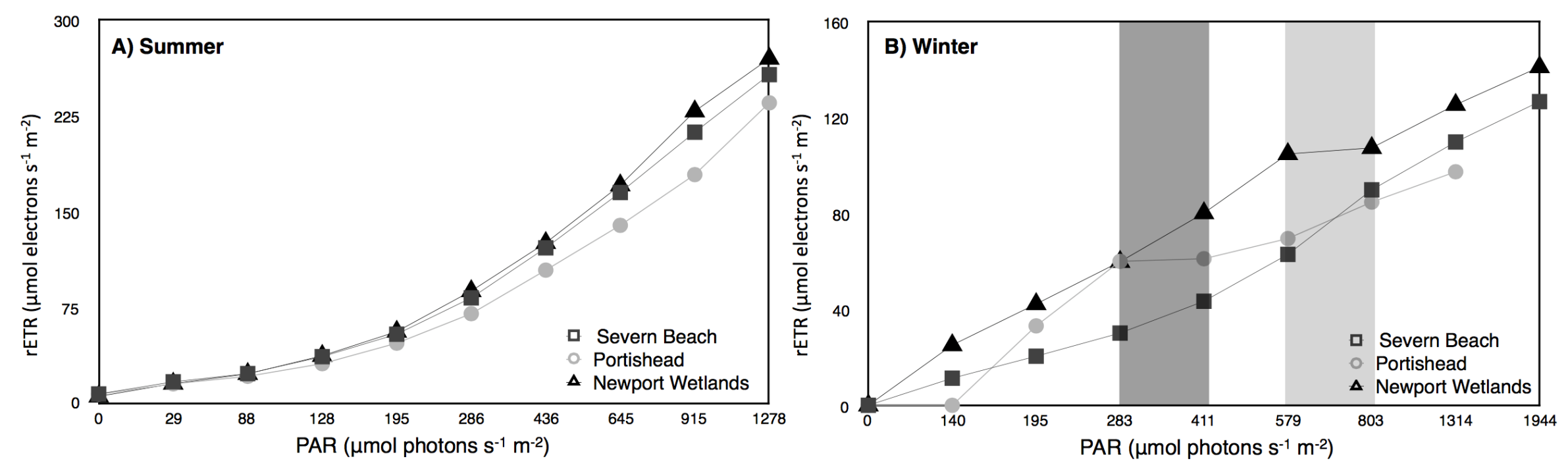

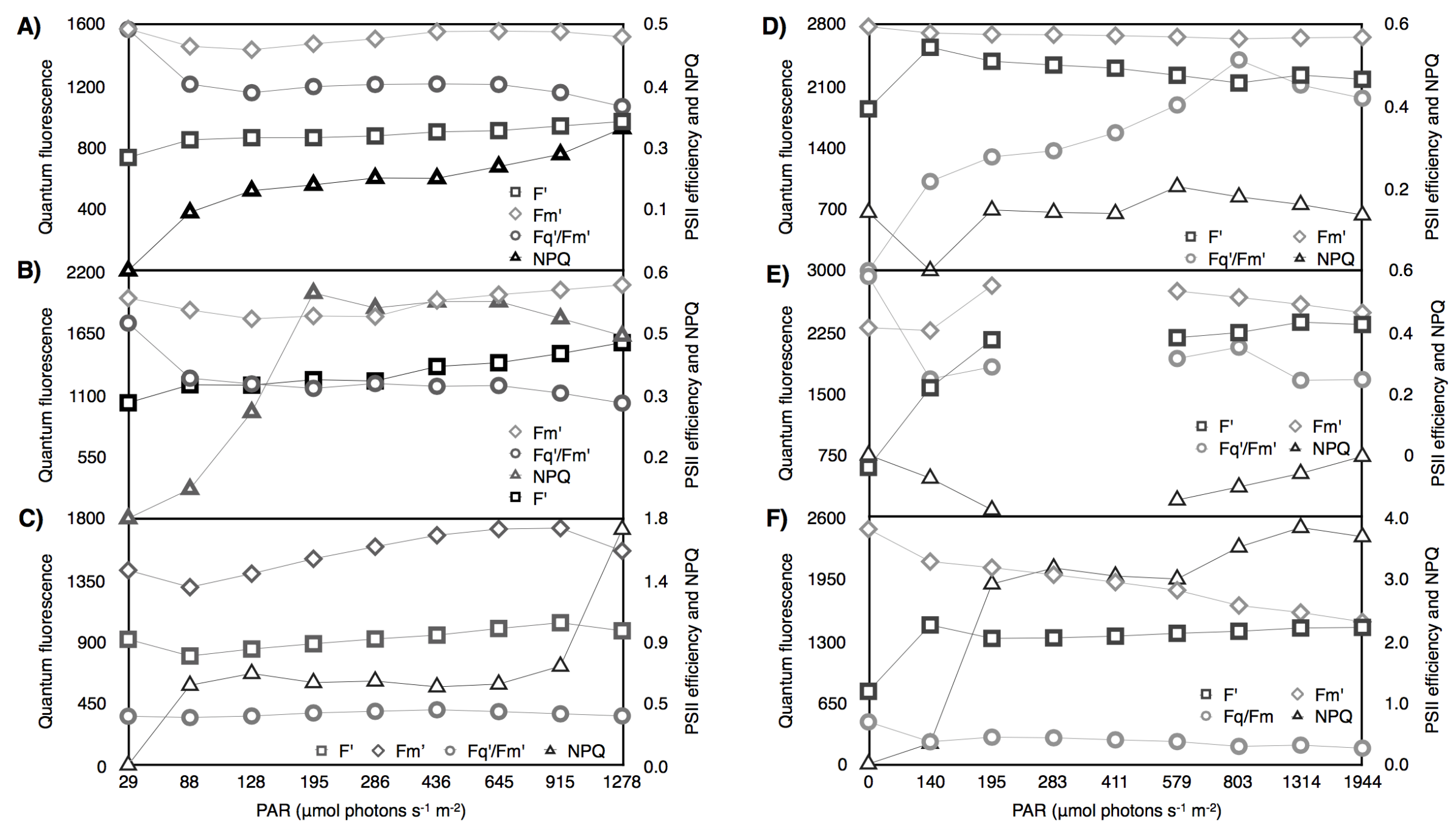


\begin{tabular}{|c|c|c|c|c|c|c|c|c|c|c|c|c|c|c|c|c|}
\hline & \multicolumn{8}{|c|}{ Summer } & \multicolumn{8}{|c|}{ Winter } \\
\hline & \multicolumn{2}{|c|}{ Site 1} & \multicolumn{2}{|c|}{ Site 2} & \multicolumn{2}{|c|}{ Site 3} & \multicolumn{2}{|r|}{ All } & \multirow{2}{*}{\multicolumn{2}{|c|}{$\begin{array}{ll}\text { Site } 1 \\
\end{array}$}} & \multicolumn{2}{|c|}{$\begin{array}{l}\text { Site } 2 \\
\text { S }\end{array}$} & \multicolumn{2}{|c|}{ Site 3} & \multicolumn{2}{|r|}{ All } \\
\hline \multirow{2}{*}{\multicolumn{17}{|c|}{ BBSi drivers }} \\
\hline & & & & & & & & & & & & & & & & \\
\hline BDSi vs. BBSi & 12 & 0.017 & 12 & -0.242 & & -0.349 & & 0.105 & & 0.105 & & -0.048 & & 0.271 & & 0.168 \\
\hline P vs. BBSi & 12 & 0.120 & 12 & 0.413 & 12 & & 36 & -0.434 & 12 & -0.269 & 12 & 0.163 & 12 & -0.256 & 36 & 0.223 \\
\hline Chl $a$ vs. BBSi & 12 & -0.010 & 12 & -0.049 & 12 & 0.226 & 36 & 0.296 & 12 & 0.411 & 12 & -0.607 & 12 & 0.541 & 36 & -0.264 \\
\hline $\mathrm{rETR}_{\max }$ vS. BBSi & 11 & -0.679 & 11 & 0.001 & 12 & -0.471 & 34 & -0.136 & 3 & 0.877 & 5 & -0.410 & 10 & -0.617 & 18 & -0.058 \\
\hline & & -0.259 & 11 & 0.380 & 12 & -0.220 & 34 & $\begin{array}{l}-0.289 \\
\end{array}$ & 3 & -0.185 & & 0.604 & 10 & -0.411 & 18 & 0.203 \\
\hline$F_{v} / F_{n}$ & \begin{tabular}{|l|l|}
11 \\
\end{tabular} & -0.326 & 11 & 0.382 & 12 & -0.224 & 35 & -0.291 & 10 & -0.058 & & -0.292 & 12 & 0.038 & & 0.001 \\
\hline NPQ vs. BBSi & \begin{tabular}{|l|}
11 \\
\end{tabular} & 0.552 & 11 & 0.127 & 12 & 0.761 & 34 & 0.289 & 3 & -0.115 & 4 & 0.557 & 10 & -0.0 & 17 & 0.226 \\
\hline \multicolumn{17}{|l|}{ BDSi drivers } \\
\hline P vs. BDSi & 12 & 0.160 & 12 & 0.444 & 12 & & 36 & -0.248 & 12 & 0.358 & 12 & 0.325 & & -0.485 & 36 & \begin{tabular}{|l|l|l|l|} 
& -0.115 \\
\end{tabular} \\
\hline Chl $a$ vs. BDSi & 12 & 0.498 & 12 & 0.309 & 12 & -0.239 & 36 & 0.160 & 12 & -0.480 & 12 & 0.313 & 12 & 0.100 & 36 & -0.022 \\
\hline $\mathrm{rETR}_{\max }$ vS. BDSi & 11 & & 11 & -0.247 & 12 & -0.018 & 34 & 0.069 & 3 & -0.151 & 5 & -0.011 & 10 & -0.026 & 18 & 0.010 \\
\hline$S$ & \begin{tabular}{|l|l|}
11 \\
\end{tabular} & -0.244 & 11 & 0.380 & 12 & & 34 & -0.160 & 3 & & 5 & & 10 & 0.207 & 18 & -0.040 \\
\hline$F_{v} / F_{m}$ vs. BDSi & 11 & -0.215 & 11 & -0.409 & 12 & 0.061 & 35 & -0.135 & 10 & 0.205 & 5 & -0.211 & 12 & 0.209 & 32 (32 & 0.147 \\
\hline NPQ vs. BDSi & \begin{tabular}{|l|}
11 \\
\end{tabular} & 0.018 & 11 & 0.044 & 12 & -0.082 & 34 & -0.053 & 3 & -0.972 & 4 & 0.193 & \begin{tabular}{|l|}
10 \\
\end{tabular} & -0.328 & 17 & -0.286 \\
\hline
\end{tabular}




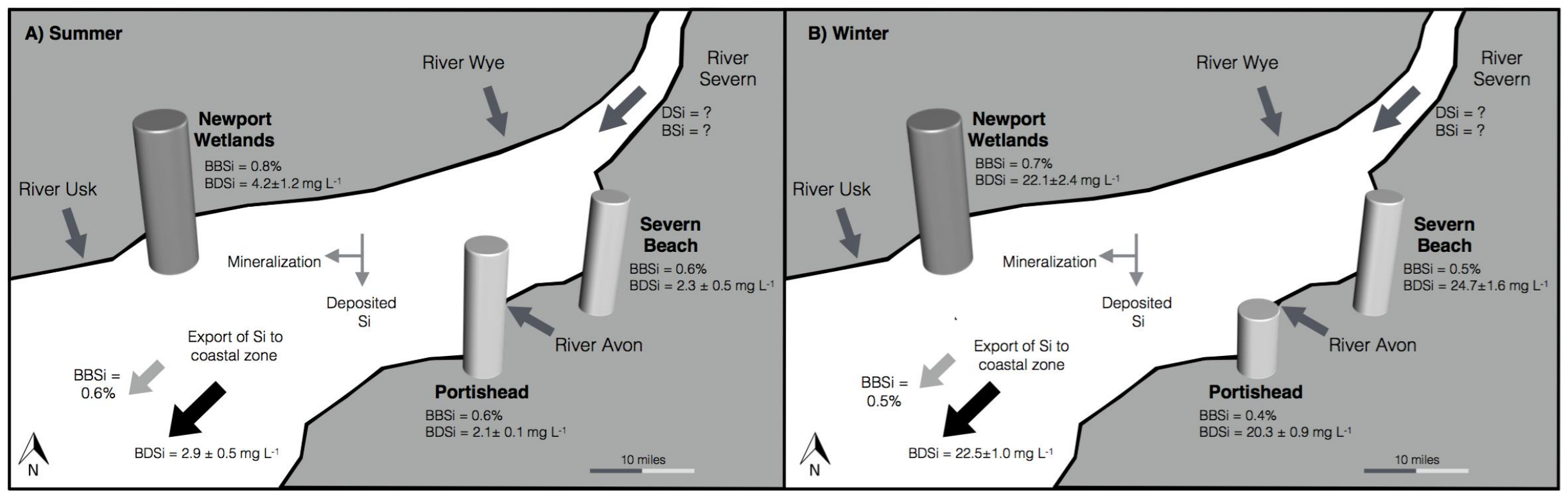

